\title{
Windows of Opportunity or Windows of Exclusion? Changing Dynamics of Tenurial Relations in Rural Ghana
}

\author{
Festus A. Asaaga ${ }^{a, b^{*}}$, Mark A. Hirons ${ }^{\mathrm{a}}$ \\ ${ }^{a}$ Environmental Change Institute, University of Oxford, Oxford OXI 3QY, UK. \\ ${ }^{\mathrm{b}}$ Centre for Ecology and Hydrology, Maclean Building, Crowmarsh Gifford, Wallingford OX10 8BB, \\ Oxfordshire, UK \\ Email: fesasa@ceh.ac.uk/ fasaaga@gmail.com Email : mark.hirons@ouce.ox.ac.uk
}

\begin{abstract}
Central to contemporary debates on land tenure in sub-Saharan Africa are questions concerning appropriate pathways to successfully harmonize customary and statutory land tenure arrangements to address normative goals of improving access to land and security of tenure for the poor and marginalized. These are particularly prevalent in the face of increasing commodification and individualisation of land rights. Developing appropriate land policies requires a detailed understanding of existing tenurial dynamics. This paper draws on a mixture of qualitative methods and a household survey among 380 farmers from 19 villages in the Kakum and Ankasa areas of southcentral and western Ghana, to explore the mechanisms of land access, control and ownership arrangements, focusing on key differentiations around gender, age and ethnicity. The results articulate how transformations in land tenure have shifted patterns of accessing land in favour of wealthier individuals to the relative disadvantage of women, young people and poor people regardless of ethnicity. The analysis further indicates that the 'self-transformation' or dynamism of local customary tenure arrangements is inadequate for addressing issues of challenges in access to and control of land, particularly by the vulnerable social groups. This is evidenced by some traditional authorities and local powerful elites capitalizing on the 'new opportunities' afforded by the emergent tenurial relations to advance their individual interests at the expense of the vulnerable groups. Overall, the study highlights how on-going changes in customary tenure arrangements towards individualisation are far more complex and socially embedded than is often assumed. The paper underscores the need for land policy reforms to shift away from static approaches geared towards promoting efficiency or merely lauding customary tenure arrangements towards more flexible approaches that accommodate the complexity of contemporary changes to land tenure arrangements.
\end{abstract}

Keywords - Land Tenure, Customary land tenure, Statutory land tenure, Ghana, SSA 


\section{Introduction}

Land tenure arrangements, that define the conditions of access ${ }^{1}$ to and control of land, are widely held to be central to sustainable development, particularly in rural contexts where livelihoods are inextricably linked to access to land resources (Yaro, 2010; Bugri, 2008; de Soto, 2000; Byamugisha, 2013; Falk, 2016; Rudel and Hernandez, 2017). In sub-Saharan Africa (SSA), including Ghana, debates revolve around the role of customary tenure systems ${ }^{2}$ and how to integrate them within ongoing reforms to enhance security of access and tenure especially for vulnerable social groups like women, youth and the poor (Krantz, 2015; Arko-Adjei, 2011; Knight, 2010; Kidido et al. 2017). Whereas there is widespread consensus that customary tenure arrangements in SSA are changing in the face of increasing commoditization and land scarcity (Cotula et al. 2007; Peters, 2013; Kalabamu, 2014), the ways in which customary tenure institutions respond to such changes vary significantly based on the marked differences or diversity of the local contexts (Cotula et al. 2007; Yaro, 2010; Lambrecht and Asare, 2016). Yet there is insufficient empirical evidence that characterizes how contemporary customary tenure arrangements are changing, the patterns and trajectories of their transformation and the responses of traditional authorities to these changes. Understanding these processes and their implications for access and control dynamics is critical for assessing the effectiveness of customary tenure arrangements in safeguarding equitable land access by different social groups as well as implementing appropriate policy interventions necessary for promoting long-term livelihood security (Lawry et al. 2017; Mwesigye et al. 2017; Anaafo, 2015; Kidido et al. 2017). This is particularly important considering the failure of previous land reforms which adopted an overly simplistic approach of supplanting African customary tenure systems with western-styled (statutory) tenure without a detailed understanding of the complexity of African customary tenure systems (Bugri, 2012; Okoth-Ogendo, 2002; Nkwae, 2006).

This paper examines the complexities of contemporary customary tenure arrangements, practices (in terms of access to and control of land by different social groupings) and how traditional institutions are responding to these changes in the face of increasing land scarcity and commodification in the context of two cocoa growing regions in southern Ghana. The paper specifically aims to (1) investigate how the tenure transformation processes has triggered the redefinition of local norms and rules governing land access and control, and (2) articulate the implications of these for equitable land access and tenure security in the study areas.

The paper proceeds as follows. In Section 2, we explore existing land tenure debates in SSA relating that to the ongoing transformation in customary land governance in Ghana. In Section 3, we describe

\footnotetext{
${ }^{1}$ The concept of access used in this paper generally refers to the means of benefitting from land be it rooted in dejure or de facto claims to land, after Ribot and Peluso (2003).

${ }^{2}$ Customary tenure refers to the tenure usually associated with indigenous communities and administered with their customs and norms as opposed to statutory tenure consisting of formal rules governing access and ownership usually introduced during and after the colonial period (Food and Agriculture Organization, 2002: 48).
} 


\section{Land Use Policy}

the research methodology followed by the results and discussion in Sections 4 and 5 respectively. The paper concluding aspect of the paper reflects on the implication of the findings for burgeoning debates on land tenure in SSA.

\section{Land Tenure Debates in sub-Saharan Africa - Situating Ghana}

\subsection{Overview}

Recent evidence on the changing dynamics of land tenure in sub-Saharan Africa generally show an increasing incidence of customary tenure systems evolving towards individualisation accelerated by growing population pressures and changing socio-economic conditions (Quisumbing et al. 2001; Chimhowu and Woodhouse, 2006; Cotula et al. 2007; Otsuka and Place, 2014). While this evolution of customary tenure directly reflects Platteau's $(1996,2000)$ evolutionary thesis on land rights development in sub-region ${ }^{3}$, the phenomenon has raised widespread concerns about the long-term security of customary land rights and the implications for access and control given the growing scarcity and commodification of land (Amanor, 2010; Otsuka and Place, 2014; Kalabamu, 2014). This is particularly important in SSA's predominantly rural context (including Ghana) where customary land tenure continues to govern the land relations of over 90 percent of the rural population (Deininger, 2003; Knight, 2010; Garber, 2012; Byamugisha, 2013). Available statistics suggest that only between 2 and 10 percent of rural land is held under formal freehold title in SSA (Deininger, 2003: 78; Chimhowu and Woodhouse, 2006: 346).

Against this background, debates on the relevance of African customary tenure institutions in safeguarding equitable land access and tenure security continue to gain traction and are centered on three main perspectives: (1) formalization, (2) communitarian and (3) adaptation perspectives. These arguments are briefly synthesized and provides a useful background for situating the subsequent analysis on how customary tenure arrangements in the case study areas are changing. First, proponents of the formalisation perspective primarily argue that customary tenure institutions are incapable of safeguarding equitable access and tenure security in the face of ongoing changes in local land tenure dynamics (La Anyane, 1962; Whitehead and Tsikata, 2003; Quan and Antwi, 2008; Goldstein and Udry, 2008). Indeed, some advocates of this view maintain that customary tenure institutions are not transparent and suffer from manipulations by some powerful local elites and traditional authorities (occasioned by the inherent power imbalances) to the detriment of the poor and vulnerable groups (Amanor, 2006; Whitehead and Tsikata, 2003; Ubink, 2008; Schoneveld and German, 2014). It is in this regard that Nkonya et al. (2016), Antwi-Adjei et al. (2015) and Damnyag et al. (2012) have proposed the restructuring of customary land tenure systems to guarantee equitable access, tenure security and investments in sustainable land management. Yet empirical evidence on land tenure reforms in SSA largely suggest their introduction have failed to

\footnotetext{
${ }^{3}$ The evolutionary theory of land rights (ETLR) as proposed by Platteau $(1996,2000)$ has been widely used to explain the nature and development of customary tenure systems in the specific context of SSA. A central tenet of this theory is that "under the combined impact of increasing population pressure and market integration, land rights spontaneously evolve towards individualisation and this evolution ultimately leads landholders to demand for the establishment of formalized private property rights - a demand which the state will have an incentive to respond" (Platteau, 1996: 29). While recognising its limitations (see Yngstrom, 2002; Garber, 2012), drawing on the ETLR helps to capture and shed light on how various land ownership structures and access mechanisms within customary tenure arrangements are evolving and the implications for the land rights of different categories of people in the study areas.
} 


\section{Land Use Policy}

deliver the much-touted tenure security, but in some instances rather created avenues for opportunism and abuse by powerful local and external interests especially in rural areas (ArkoAdjei, 2011; Meinzen-Dick and Mwangi 2009; Lawry et al. 2017; Bromley, 2009).

On the contrary, advocates of the communitarian argument have debunked the idea that customary tenure arrangements are an impediment to agricultural development and sustainable land management. They emphasize that the inherent 'social security' and egalitarian features of customary tenure arrangements ensure equitable access to land by all members of the landholding community to the extent that there is no landlessness as well promote ecological preservation (Berry, 1993; 2009; Kasanga, 1996, 2001). Supporters of this view further argue that the customary tenure arrangements are resilient and dynamic not constraining investments in sustainable land management (Abdulai and Ndekugri, 2007; Blocher, 2006; Bromley, 2009; Kasanga and Kotey, 2001). They prescribe a decentralized approach to land management at the local level as opposed to a state-centric approach. A corollary of this debate is the polarized understanding of the terminology 'customary' which some scholars (e.g. Peters, 2009; Ubink, 2009; Amanor, 2001) contend may be an outcome of manipulation and reinterpretation to serve the interests of the elites in society.

Away from the customary-statutory tenure dichotomy, recent scholarship has advocated for an integration or 'marriage' of these two tenure systems to ensure that the ills of one system is offset by the strengths of the other, thereby effectively addressing the questions of access and tenure security (Blocher, 2006; Clarke, 2009; Knight, 2010; Arko-Adjei, 2011). This derives from the widespread recognition that neither a wholly customary nor statutory tenure system can deliver on tenure security in SSA given the conceptual divergence between these two systems (World Bank, 2003; Nkwae, 2006; Arko-Adjei, 2011).The lack of conceptual and policy consensus on nature of customary tenure arrangements is underpinned by a dearth of empirical evidence concerning these supposedly 'informal' institutions and the socio-political dynamics that underpin them within the contemporary context (Okoth-Ogendo, 2000, Whitehead and Tsikata, 2003; Appiah, 2012; Verma, 2014; Lambrecht and Asare, 2016). A context-specific understanding of tenurial regimes within the purview of political and socio-demographic change in SSA is important in appropriately designing and targeting land policy interventions to engender efficient and equitable social and economic outcomes. The next section presents an overview of contemporary customary land governance in Ghana to provide a contextual background to situate the subsequent empirical analysis in Section 4.

\subsection{Contemporary Customary Land Governance in Ghana}

Although land governance in Ghana is based on a pluralistic legal framework (comprising of stateenacted legislations and locally-derived customary laws), the customary land tenure system remains the dominant tenurial regime particularly in the rural agricultural zones. Nearly 80 per cent of all land in Ghana is controlled by traditional authorities (with the remaining $20 \%$ controlled by the state) which highlights the important role of customary tenure institutions in land management, albeit with a "a heavy statutory overlay" (Agbosu et al. 2007; Kasanga and Kotey, 2001). Within this purview, the traditional authorities (represented by chiefs, elders and clan/ lineage heads) control and manage customary lands in a fiduciary capacity as a representation of the collective 


\section{Land Use Policy}

landholding community (Ollenu, 1962; Bentsi-Enchill, 1964; Article 36(8) and 267 (1) of 1992 Constitution of Ghana; Kasanga and Kotey, 2001), with some local variations between regions and individual communities (Agbosu et al. 2007; Yaro, 2010). Yet developments in customary land governance in Ghana, synonymous to developments in other parts of SSA, highlight some marked changes overtime resulting in the gradual erosion of the fiduciary principle and the transition towards individualisation based on the commodification of customary land (Kasanga and Kotey, 2001; Yaro, 2010; Barry and Danso, 2014; Lambrecht and Asare, 2016). Indeed, several studies have observed customary land administration and institutions have undergone profound changes dating back to the colonial, post-colonial into their present state (Agbosu et al. 2007; Joireman, 2008; Akuffo, 2009; Woodman, 2011). Of particular importance is the series of interventions introduced by successive governments (through the colonial to the post-independence era) intended to restructure the supposedly inefficient and anachronistic customary tenure arrangements which have rather operated to entrench the hegemonic positions of traditional authorities regarding control over communal land (Berry, 1993; Agbosu et al. 2007; Djokoto and Opoku, 2010) as well as instigated the rapid transformation towards individualised ownership (Kuusaana and Gerber, 2015). Several studies (Firmin-Sellers, 1995; Mamdani, 1999; Akuffo, 2009; Djokoto and Opoku, 2010) have noted a myriad of internal and external factors instigating the transformation of customary tenure arrangements and institutions, including colonialism, urbanization, large-scale farmland acquisitions amongst other associated forces. For instance, the British introduction of the indirect rule policy in the 1900s led to significant transformation the pre-existing tenurial relations and institutions as traditional authorities (including local chiefs, village leaders and lineage heads) were co-opted into the colonial politico-administrative machinery and new traditional structures created as an effective means of controlling the indigenous population and the natural resources endowments (see Mamdani, 1999; Djokoto and Opoku, 2010; Akuffo, 2009; Berry, 2002; OkothOgendo, 2002; Amanor, 2012; Joireman, 2006). A case in point was the recognition of chiefs as the radical allodial title holders (Pottier, 2005; Berry, 2002; Amanor, 2012) which has been consistently upheld and entrenched in all four republican constitutions of Ghana (Kuusaana and Gerber, 2015).

Some scholars (Kasanga, 2002; Cotula, 2007) have also argued that while colonial impact on customary tenure institutions is important, it should not be overemphasized in the postindependence era. Indeed, successive governments in the immediate post-independence era, particularly from the 1960s, have made various important changes to the land market through various legislations to accelerate land privatization and commodification (Kuusaana and Gerber, 2015). The operational effect of these legislative enactments was the entrenchment of the dualised, unequal and hierarchical tenurial framework characterised by protracted land disputes, multiple land claims, insecurity and exclusion, particularly among the vulnerable social groups such as women, youth, migrant and the poor (Government of Ghana, 1999; Kasanga and Kotey, 2001; DowuonaHammond, 2003; Arko-Adjei, 2011; Boone and Duku, 2012).

Against this backdrop, subsequent attempts at addressing the challenges of land administration in Ghana led to a suite of policy and legislative reforms, notable of which is the National Land Policy (NLP) in 1999 and its subsequent operationalisation framework the Land Administration Project 


\section{Land Use Policy}

$(\text { LAP })^{4}$ (Government of Ghana, 1999; Quan et al. 2008). Central to the LAP reform process is the recognition of the centrality customary tenure institution to land administration in Ghana which spurred the establishment of customary land secretariats (CLSs) ${ }^{5}$ as decentralized administrative units that assist traditional authorities to improve and develop customary land administration (ArkoAdjei, 2011; Bugri, 2012). Whereas the CLSs do offer a pathway towards improved customary land delivery, several scholars (Ubink and Amanor, 2008: 16; Ubink, 2008; Amanor, 2010; Aryeetey et al. 2007) have expressed some doubt as to the CLSs being a 'game changer' particularly because of the propensity to entrench/ consolidate chiefly authority over land to the detriment of their poor and vulnerable subjects (for a discussion, see Amanor, 2010; Antwi, 2006; Yankson et al. 2009). In any event, the establishment of CLSs will lead to tenurial re-engineering in customary areas requiring that the land rights of vulnerable groups and possible elite capture of the land governance process should be anticipated and progressively addressed (cf. Bugri, 2012). This underscores the need for better understanding of the contemporary dynamics of land access, particularly in rural customary dominated contexts. The next section describes the methods used in this paper.

\section{Materials and Methods}

\subsection{Study Locations}

The study was undertaken in 19 forest-fringe communities randomly selected in the Kakum and Ankasa Conservation Areas in South-Central and Western Ghana respectively between December 2013 and September 2015. The Kakum and Ankasa Conservation Areas form part of the 8.2 million ha stretch of the high forest zone spanning the entire southern third of Ghana ${ }^{6}$. In terms of composition, both the Kakum and Ankasa landscapes are dominated by the permanently protected Kakum National Park and Ankasa National Park and surrounding communities, spanning a total area of $360 \mathrm{~km}^{2}$ and $509 \mathrm{~km}^{2}$ respectively (see Fig. 1). The selection of Kakum and Ankasa contexts for in-depth investigation was based on the convergence of a number of theoretical and empirical considerations including: (1) the authors familiarity with the Kakum and Ankasa contexts as exemplifying the prevailing tenurial situation across Ghana's High Forest Zone, (2) the little attention paid to tenurial issues in Kakum and Ankasa in more recent times with the notable exception of (Damnyag et al. 2012), and (3) the intensifying land pressures particularly from agriculture resulting in growing inequalities over land access, conflicts and extensive deforestation in the study areas with negative implications for livelihoods and environmental sustainability in the areas (ibid; 2013; Braimah et al. 2009).

\footnotetext{
4 The G-LAP is a 15-25-year programme designed to reform land-sector institutions and to develop land policy to provide security of tenure for landholders and promote efficiency in the land market (Quan et al. 2008).

${ }^{5}$ The CLSs operate as the interface between customary and public land sector agencies and are governed by the chiefs and heads of clans and families through their respective land management committees (Bugri, 2012: 8). 37 CLSs have so far been established across the country which have made considerable strides in improving customary land administration (see Bugri, 2012; Biitir and Nara, 2016).

${ }^{6}$ Ghana's high forest zone covers about 7\% of Ghana's total land area (Agidee, 2011). The zone provides an interesting setting for analysing the complexity of tenurial dynamics given the growing land pressure and associated conflicts occasioned by the concentration of most land-based economic activities, including cocoa, oil palm, timber, rubber and mining in the zone.
} 


\section{Land Use Policy}

Aside from having similar tenurial and social contexts ${ }^{7}$ affording comparability, both study sites form part of the cocoa growing landscapes in Ghana. Within this context, cocoa, oil palm and food crop farming are the dominant economic activities undertaken by households on relatively smaller plots $(<5$ ha), working the land under diverse tenurial arrangements, ranging from customary freehold to customary licenses. The creation of the reserves vis-à-vis the growing local population has reduced cultivable land in the surrounding off-reserve areas resulting in uncontrolled land use conversion (mostly to cocoa), habitat loss and widespread degradation. Thus, while the two case studies are not representative of the whole Ghana (particularly the patrilineal-oriented settings) considering the strong contrast in tenurial arrangements (Kasanga and Kotey, 2001; Bugri and Yeboah, 2017), situating this study within the Kakum and Ankasa contexts affords an understanding of the complexities of changing tenurial dynamics towards formulating appropriate land policy interventions for livelihood security and long-term environmental sustainability in high forest zone and Ghana more generally.

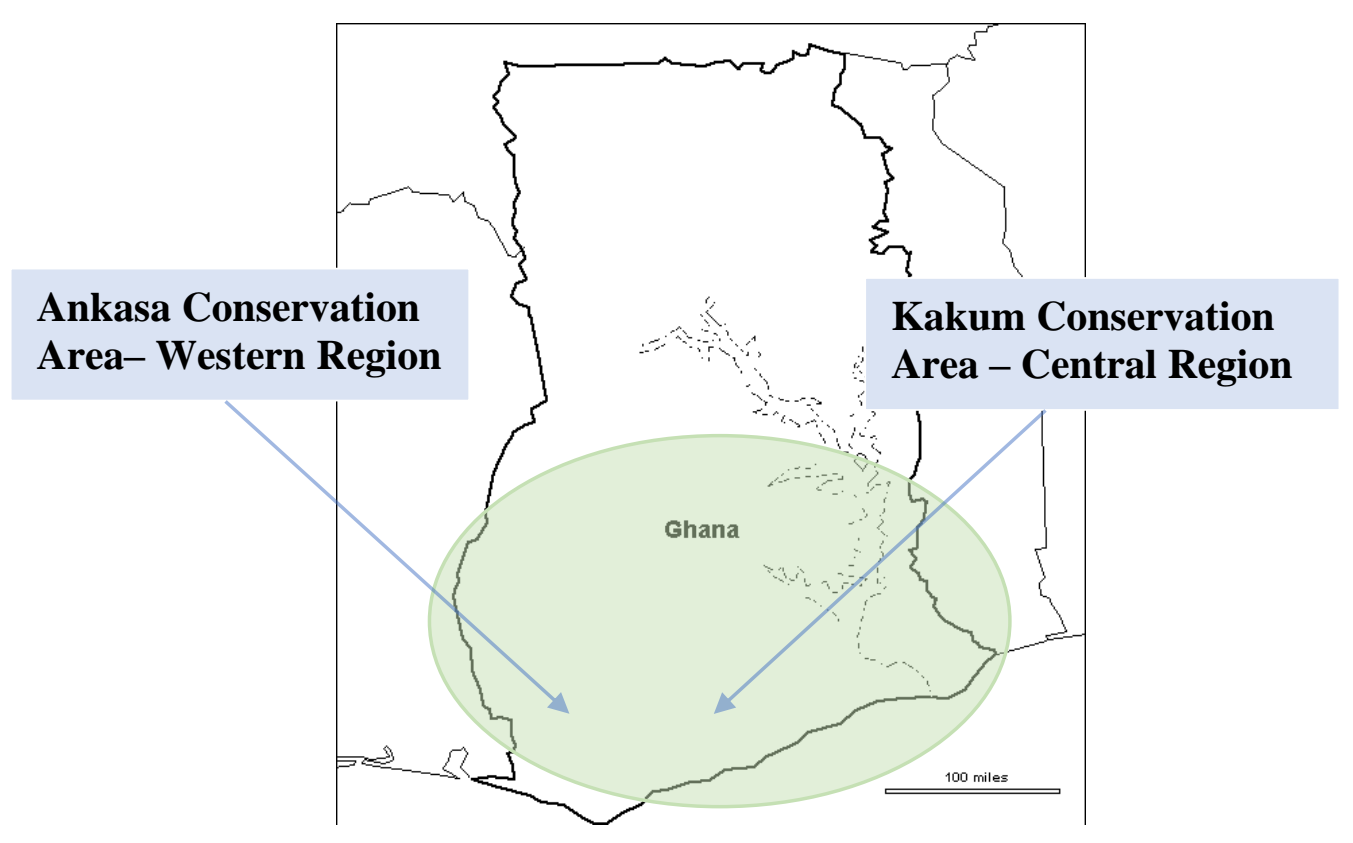

Fig. 1: Overview of the two study sites in Ghana. Green Area illustrates the HFZ. Source: Author's modification of outline map from www.enhantedlearning.com.

\subsection{Data Collection and Analysis}

To explore the complexities of changing tenurial dynamics and their implications for land access and control dynamics in Ghana, a mixed methods approach was adopted. The qualitative data comprised of in-depth individual interviews, focus group discussions with male and female participants in single and mixed-gender groups (in 8 communities) and key informant interviews with the local stakeholders in customary land administration (including community leaders, officials

\footnotetext{
${ }^{7}$ Synonymous to other communities in the high forest zone of southern Ghana, the customary land tenure relations in Kakum and Ankasa fall within a matrilineal land inheritance tenure typology. This implies that land is traditionally bequeath through the maternal lineage. Conversely, communities in northern Ghana are characterised by the patrilineal land inheritance system with land traditionally bequeath through the paternal lineage (see Yaro, 2010; Bugri, 2008).
} 


\section{Land Use Policy}

of the CLS and OASL) and the National Land Administration Project Secretariat ${ }^{8}$. Apart from the formal interviews and FGDs, 'focused interviews' (Yin, 2003: 90, 91) with some key informants were also employed as a 'side-technique' to help triangulate the validity of information collated during the interview and FGD sessions. The interviews mainly revolved around respondents' views of tenurial practices, conditions of land rights and tenure security etc. which was analysed following the standard qualitative data analysis approach by Miles and Huberman (1994). The selection of interviewees was based on purposive and continuous snowballing sampling techniques with interviews mainly conducted in $\mathrm{Twi}^{9}$, the predominant local language spoken in the studied communities.

The qualitative data was supplemented with household surveys conducted (between January 2014 and September 2015) with 148 randomly sampled households in Ankasa and 232 households in Kakum respectively. The household survey sought to collate data on the different mechanisms and processes of land acquisition, conditions of access among others across the different key social groups, gender, age and ethnicity (autochthonous/indigenous or heterochthonous/migrants). Aside from these socio-demographic categorizations widely recognised as important in local tenurial relations (Peters, 2009; Lund, 2011; Lambrecht, 2016; Kidido et al. 2017), such disaggregation afforded a more nuanced understanding of how patterns of differentiation regarding access and control mechanisms are manifested. Notably, the majority of households (320 or $84 \%$ ) surveyed were male-headed, with 60 female-headed ones reflecting the dominance of men in land use decision-making even in matrilineal settings (Bugri and Yeboah, 2017; Duncan, 2010).

We acknowledge that the gender disproportionate sample could be a limitation of this study to the extent that women constitute the majority of smallholder farmers in Ghana and SSA generally (Sewornu, 2010; Doss et al. 2015; Lambrecht, 2016), contributing 60\% to the growth of Ghana's agricultural sector (GNA, 2018). The findings cannot therefore be regarded as representative of the views of all women groups on tenurial issues in the study contexts and Ghana more generally. The careful composition of the FGDs, however, afforded in-depth qualitative insights into the perceptions and experiences of women regarding changing tenurial dynamics in the study areas. More so, a key empirical strength of this study is the plot-level (as opposed to aggregated land holdings) analysis adopted which sheds additional light on important differences (in terms of access and control dynamics) that may exist across different household plots which otherwise would have been obscured or difficult to unpack. The survey data were analysed using SPSS and triangulated with the qualitative data and other relevant secondary information collated based on which inferences and conclusions were drawn (Creswell, 2013; Creswell and Clark, 2011). The ensuing sections present the main results of the study followed by a discussion on the implications of study findings for equitable land delivery in Ghana and SSA in Section 5.

\section{Results}

\footnotetext{
8 Aside from the institutional respondents who were directly contacted in their respective offices, access to community-level stakeholders was negotiated through the traditional authorities (or "gatekeepers" as qualified by Hammersley and Atkinson, 2007) such as chiefs, Odikros and Abusuapanyins who were themselves interviewed.
}

${ }^{9}$ Twi is the most widely spoken language amongst the Akan tribal groupings of southern Ghana. 


\section{Land Use Policy}

\subsection{Land Ownership and Access in the study areas - A Contemporary Overview}

To interrogate the nuances of the impacts of the transition towards individualization and commodification of land, it is useful to provide an idealized model of land ownership in Ghana's high forest zone with which to contrast empirical data. Figure 2, developed from interviews with key informants, shows the theoretical architecture of land ownership in the study contexts, and table 1 provides a fine-grained description of the various tenurial arrangements that exist in the study areas.

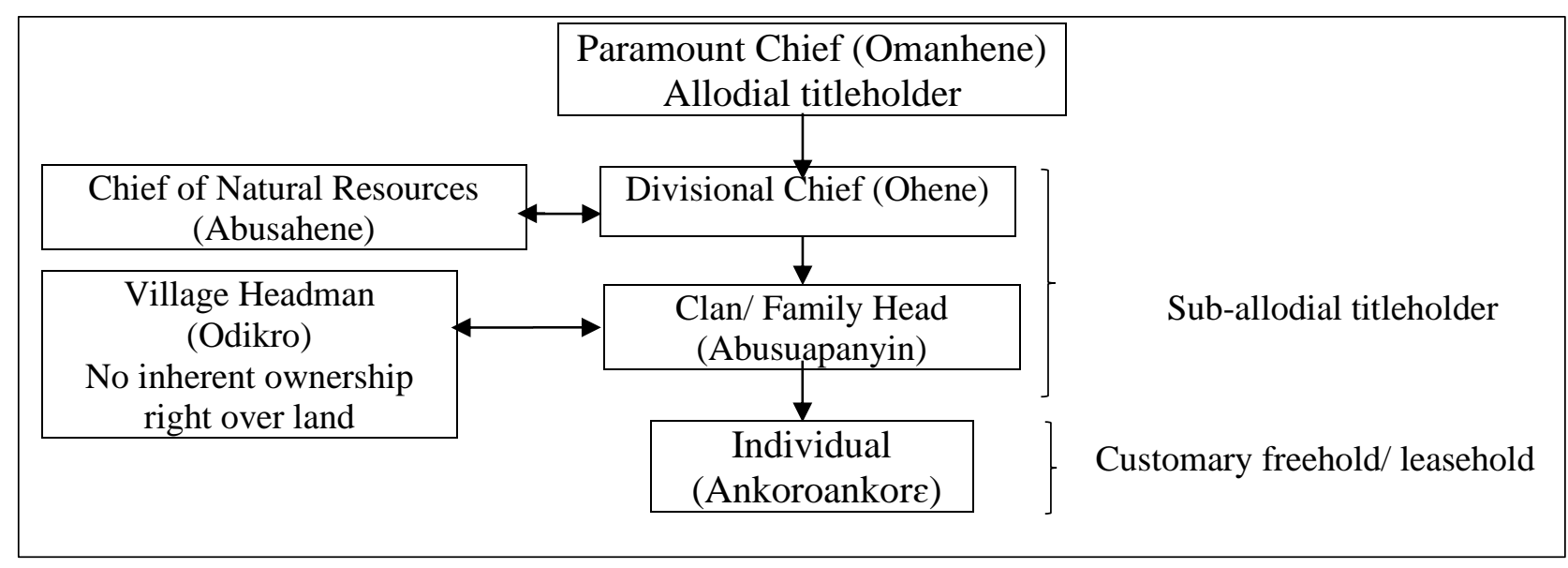

Figure 2: An idealized structure of land ownership in the study areas.

Table 1: Various forms of tenure in the study areas

\begin{tabular}{|c|c|}
\hline Tenure Form & Salient Features and Remarks \\
\hline $\begin{array}{l}\text { Customary } \\
\text { Freehold }\end{array}$ & $\begin{array}{l}\text { - Subservient only to the allodial title. } \\
\text { - Independent control over land use and management decision-making. } \\
\text { - Effectively permanent and inheritable subject to full observance of the } \\
\text { conditions of grant. } \\
\text { - Differences between individual land users and traditional authorities } \\
\text { about alienability. }\end{array}$ \\
\hline $\begin{array}{l}\text { Abunu } \\
\text { (Division } \\
\text { Two }^{10}\end{array}$ & $\begin{array}{l}\text { - Subservient to the customary freehold interest and allodial title. } \\
\text { - Independent control over land management decision-making. } \\
\text { - Inheritable property (i.e. crop on the land). } \\
\text { - Somewhat permanent subject to the maintenance of the 'property' thereon. } \\
\text { - Alienable property but not land per se. }\end{array}$ \\
\hline Apaso Abunu & $\begin{array}{l}\text { - Subservient to the customary freehold and allodial title. } \\
\text { - Somewhat independent control over land management decision-making (subject } \\
\text { - Io approval of landowner). } \\
\text { - Inheritable property (i.e. crop on the land). } \\
\text { - Indeterminate subject to full observance of conditions of grant. } \\
\text { - Non-alienable to a third party. }\end{array}$ \\
\hline Abusa & - Subservient to the superior interest from which it was carved. \\
\hline
\end{tabular}

${ }^{10}$ The abunu and abusa are variants of sharecropping agreements. Under the abunu system, two forms are identifiable - dua mmicnkye or division two (where the tree crops say, cocoa are divided into two including land and the tenantfarmer's portion remains with him/ her permanently) and apaso abunu (where the farm proceeds are equally shared between landlord and tenant). In the case of the abusa system, the proceeds from the sale of farm produce is shared in the ratio $1: 2$ between landowner and tenant-farmer respectively. 


\begin{tabular}{|c|c|}
\hline & $\begin{array}{l}\text { - Partial/ limited control over land management decision-making (subject to } \\
\text { approval of landowner). } \\
\text { - Inheritable property. } \\
\text { - Indeterminate subject to full observance of conditions of grant. } \\
\text { - Non-alienable to a third party. }\end{array}$ \\
\hline Rental & $\begin{array}{l}\text { - Fixed duration subject to observance of full conditions of grant. } \\
\text { - } \quad \text { Partial control over land management decision-making. } \\
\text { - Non-inheritable property. } \\
\text { - Non-alienable to a third party. }\end{array}$ \\
\hline Caretaker & $\begin{array}{l}\text { - No legal interest in the said property and/ or land. } \\
\text { - No control over land management decision-making. } \\
\text { - Non-inheritable property. } \\
\text { - Non-alienable and indeterminate duration. }\end{array}$ \\
\hline $\begin{array}{l}\text { Customary } \\
\text { Licenses } \\
\text { (Permissions) }\end{array}$ & $\begin{array}{l}\text { - No legal interest in the said property and/ or land. } \\
\text { - No control over land management decision-making. } \\
\text { - Non-inheritable property. } \\
\text { - Non-alienable and indeterminate duration }\end{array}$ \\
\hline
\end{tabular}

Figure 2 suggests well-defined roles played by the different stakeholders, with the Omanhene having the ultimate control over land within this hierarchal structure. However, this does not reflect the actual tenurial practices which are complex and highly contested due to actors taking on a range of different roles. For example, it was revealed that these different actors on the customary power scale (including the Odikros and lessees) sometimes entered into transactions with tenant farmers disguising as actual landowners with the capacity to alienate land. Highlighting the challenges in determining patterns of ownership and authority, Table 2 shows the variability in how surveyed respondents perceived which actors own and have influence over land.

Table 2: Respondents view of Ownership and Influence by study area
\begin{tabular}{|l|c|c|}
\hline \multirow{2}{*}{$\begin{array}{l}\text { Respondents perception about who are the } \\
\text { contemporary landowners }\end{array}$} & $\begin{array}{c}\text { Kakum } \\
(\mathrm{n}=232)\end{array}$ & $\begin{array}{c}\text { Ankasa } \\
(\mathrm{n}=148)\end{array}$ \\
\hline Paramount Chief (Omanhene) & $88 \%$ & $9 \%$ \\
\hline Divisional Chief (Ohene) & $6 \%$ & $89 \%$ \\
\hline Clan/ Family head (Abusuapanyin) & $1 \%$ & 0 \\
\hline Village Headman (Odikro) & $1 \%$ & $1 \%$ \\
\hline Individual landowner & $4 \%$ & $1 \%$ \\
\hline $\begin{array}{l}\text { Respondents perception of most influential } \\
\text { actor in land management }\end{array}$ & & \\
\hline Paramount Chief (Omanhene) & $11 \%$ & $26 \%$ \\
\hline Divisional Chief (Ohene) & $52 \%$ & $39 \%$ \\
\hline Clan/ Family head (Abusuapanyin) & 0 & 0 \\
\hline Village Headman (Odikro) & $23 \%$ & $34 \%$ \\
\hline Individual landowner & $14 \%$ & $1 \%$ \\
\hline
\end{tabular}

Table 2 highlights two important points. First perceptions concerning who owns land can vary considerably between regions. In this case, the difference between areas in who is perceived to be the allodial title holder could be explained by the fact that the sub-allodial title in land in southern Ghana is often vested in Divisional Chiefs and/ or family heads of whom the paramountcy is a collective representation. Secondly, there is a divergence between who owns the land and who influences its management. While Divisional Chiefs are considered to be most influential in both 


\section{Land Use Policy}

areas, other actors like the Odikro and the ankoroankore (Individuals) were also seen to be influential. Together, these results suggest that part of the tenure complexities is rooted in differing perceptions, at a local level, concerning who owns land and who influences its management. This contradicts the conventional wisdom, rooted in the idealized model of land ownership, that Omanhene, Divisional Chiefs and Abusuapanyins are the most influential in land use and management dynamics.

In light of questions about the degree of dynamism and flexibility of customary tenure arrangements, and its impacts, it is important to investigate the different modes of land access in the studied communities. Table 3 typifies the main modes by which respondents acquired their landholdings in Kakum and Ankasa.

Table 3: Common Access Routes to Landholdings

\begin{tabular}{|l|l|l|l|l|l|l|}
\hline \multirow{2}{*}{ Area } & \multicolumn{4}{|c|}{ Mode of Acquisition } & \multirow{2}{*}{$\begin{array}{c}\text { All } \\
\text { modes }\end{array}$} \\
\cline { 2 - 7 } & Gift & Inheritance & Purchase & Sharecrop. & Rental & $100 \%$ \\
\hline Kakum (n=520 plots) & $2 \%$ & $35 \% * * *$ & $2 \%$ & $61 \% * * *$ & $1 \%$ & $100 \%$ \\
\hline Ankasa (n=243 plots) & $7 \%$ & $31 \% * * *$ & $6 \%$ & $54 \% * * *$ & $1 \%$ & $100 \%$ \\
\hline
\end{tabular}

* Significant at $\mathrm{p} \leq 0.10 ; * *$ Significant at $\mathrm{p} \leq 0.05 ; * * *$ Significant at $\mathrm{p} \leq 0.01$

The overall results show significant differences in the modes of farmland acquisition, including market (purchase, sharecropping and rental) and non-market mechanisms (inheritance and gift) employed by respondents in the study areas. Aside from landholdings acquired via inheritance and gift (non-market channels), as significant proportion of landholdings in Kakum (63\%) and Ankasa $(61 \%)$ respectively were acquired through market channels. These results highlight the extent of commercialization of land occurring in both study areas. With the notable exception of inheritance, other traditional modes of accessing land (such as borrowing, gifts and customary permissions) that were previously considered important (Benneh et al. 1996; Kasanga and Kotey, 2001; Quisumbing et al. 2001; Yaro, 2010), no longer appear to be important. Increasingly, communal lands are effectively being transferred to private ownership as a corollary of the increasing marketization and individualisation of land. The following interview extract from an official of the Assinman CLS is illustrative in this respect:

"Nowadays, it's quite common for people to out-rightly acquire communal land in this area (provided the person has the money) which was not the case about fifteen years ago...This phenomenon is contributing to the rise in land-related disputes as some family members unilaterally sell off land even without the consent of Nananom and/ or other lineage heads given the growing land demand..." (CLS-2, Kakum).

The foregoing thus questions previous assertions that customary tenure arrangements in SSA are incompatible with land markets (de Soto, 2000; World Bank, 2006). In the case of sharecropping, for instance, the shifts in access conditions have also affected their nature in terms of the usual share of farm produce as in the past. From the FGDs and key informant interviews, most respondents argued that landowners now demand 'flat rate' cash payments in return for the use of land. A typical view by one landowner in Ankasa sums up the foregoing observation:

"The sharecropping arrangement is associated with cheating and is less profitable. Nowadays, we [landowners] have also devised a strategy of only accepting cash payments. We charge based on the acreage you [farmer] cultivated..." (FGD 3, Nungua-FGD, Ankasa). 


\section{Land Use Policy}

The transition towards monetized arrangements raises questions concerning the extent to which operation of local land markets in the study areas is still shaped by existing patterns of tenurial arrangements and associated social dynamics. Respondents were asked to indicate if there were any prequalification factors that facilitated their success in gaining access to their landholdings (see Table 4).

Table 4: Criteria for Access to Land

\begin{tabular}{|l|c|c|}
\hline $\begin{array}{l}\text { What pre-qualification factors facilitated } \\
\text { access to land? }\end{array}$ & $\begin{array}{c}\text { Kakum } \\
\text { (N=520 plots) }\end{array}$ & $\begin{array}{c}\text { Ankasa } \\
\text { (N=243 plots) }\end{array}$ \\
\hline Armlength (none) & $17 \%$ & $19 \%$ \\
\hline Familial connections & $37 \%$ & $41 \%$ \\
\hline Community membership & $20 \%$ & $12 \%$ \\
\hline Landowner's friend & $18 \%$ & $19 \%$ \\
\hline Other social networks & $8 \%$ & $9 \%$ \\
\hline
\end{tabular}

The results show that membership of landholding family or community and friendship with landowners were the three principal factors that influenced respondents' initial success in acquiring their respective household landholdings. Local land markets operating in the studied communities fall short of 'open market' conditions (in terms of access to information by all and transactions being 'arm-length' in nature ${ }^{11}$ ). Evidently, despite the ongoing tenurial transformation in the study areas, the emerging land markets are still localized, informal and heavily embedded within the internal socio-political relations.

For instance, some of the community FGD participants explained that land-constrained natives desirous of farming were often able to gain access to land through their land-rich extended family relations in their respective communities. They further highlighted that such inter-familial land allocation somewhat served as an effective means to averting landlessness amongst native groups even though it could potentially cause inter-familial land conflicts and future intergenerational equity problems on the part of the land-rich familial groups (see Section 4.3). Good interpersonal and familial relationships as well as strong community networking are clearly vital attributes accessing land in the studied communities. Besides, the possession of such attributes could also have positive implications for overall social legitimation of land rights and ultimate security of tenure. This gives further credence to Berry's (1993) assertion that investment in social relations is far-reaching in terms of gaining access to land which could also potentially operate to exclude others (especially the less powerful and vulnerable groups) from land and associated benefits. The following sections discuss this with respect to gender, age and community membership.

\subsection{Gender and access to land - looking beyond the rules}

Table 5 shows areas of landholding disaggregated by gender and table 6 shows the results on the main modes of respondents' access to their landholding by gender. These tables demonstrate that although women have access to significantly less land than men, it is not because they are excluded

\footnotetext{
${ }^{11}$ An arm-length land transaction in this context implies that both the land seeker and land giver or landowner act independently and have no relationship (by blood, marriage or other business engagements etc.) to each other to influence the negotiation process and the ultimate outcome.
} 


\section{Land Use Policy}

from any particular avenue of acquiring land ${ }^{12}$. As an excerpt from an interview with a community elder in Kakum established:

"...there is no differentiation in the process of land acquisition between men and women. Women have equal right to access land just as men do if they go through the appropriate customary authorities and procedures..." (Interview 2, Kakum).

Table 5: Landholding Area by Gender

\begin{tabular}{|c|c|c|c|c|}
\hline \multirow{2}{*}{$\begin{array}{c}\text { Size of Farm } \\
\text { (Acreage) }\end{array}$} & \multicolumn{2}{|c|}{ Kakum Region } & \multicolumn{2}{c|}{ Ankasa Region } \\
\cline { 2 - 5 } & $\begin{array}{c}\text { Men } \\
(\mathrm{n}=197)\end{array}$ & $\begin{array}{c}\text { Women } \\
(\mathrm{n}=35)\end{array}$ & $\begin{array}{c}\text { Men } \\
(\mathrm{n}=123)\end{array}$ & $\begin{array}{c}\text { Women } \\
(\mathrm{n}=25)\end{array}$ \\
\hline$\leq 3$ & $20 \% * *$ & $43 \% \%^{* *}$ & $14 \%^{* *}$ & $44 \% \%^{* *}$ \\
\hline $4-6$ & $32 \%$ & $37 \%$ & $29 \%$ & $32 \%$ \\
\hline $7-9$ & $16 \%$ & $11 \%$ & $14 \%$ & $16 \%$ \\
\hline $10-12$ & $12 \%$ & 0 & $9 \%$ & $4 \%$ \\
\hline $13-15$ & $7 \%$ & 0 & $5 \%$ & 0 \\
\hline $16+$ & $13 \%$ & $9 \%$ & $29 \%^{* *}$ & $4 \% * *$ \\
\hline
\end{tabular}

* Significant at $\mathrm{p} \leq 0.10 ; * *$ Significant at $\mathrm{p} \leq 0.05 ; * * *$ Significant at $\mathrm{p} \leq 0.01$

Table 6: Common Access Routes to Landholdings by Gender

\begin{tabular}{|l|c|c|c|c|}
\hline \multirow{2}{*}{ Mode of Acquisition } & \multicolumn{2}{|c|}{ Kakum } & \multicolumn{2}{c|}{ Ankasa } \\
\cline { 2 - 5 } & \multicolumn{2}{|c|}{ Household Plots } & \multicolumn{2}{c|}{ Household Plots } \\
\cline { 2 - 5 }$(\mathrm{n}=452)$ & $\begin{array}{c}\text { Women } \\
(\mathrm{n}=68)\end{array}$ & $\begin{array}{c}\text { Men } \\
(\mathrm{n}=206)\end{array}$ & $\begin{array}{c}\text { Women } \\
(\mathrm{n}=37)\end{array}$ \\
\hline Gift & $1 \%$ & $4 \%$ & $8 \%$ & $3 \%$ \\
\hline Inheritance & $35 \%$ & $37 \%$ & $27 \%^{* * *}$ & $57 \%^{* * *}$ \\
\hline Purchase & $1 \%$ & $3 \%$ & $4 \% \%^{* *}$ & $14 \% \%^{* *}$ \\
\hline Sharecropping & $62 \%$ & $56 \%$ & $59 \%{ }^{* * *}$ & $27 \% \%^{* * *}$ \\
\hline Rental & $1 \%$ & 0 & $2 \%$ & 0 \\
\hline
\end{tabular}

While tenurial rules per se may not inhibit women from accessing land, it is clear from observing their land holdings that they are generally disadvantaged. Two intertwined factors relating to sociocultural norms and economic barriers operate in tandem to constrain women's ability to gain access to land and accordingly assert their land rights.

Despite the widespread practice of matrilineal inheritance in the study areas, women (even natives) still require intermediaries - mostly their husbands or a male relative - in negotiating access to land which helps explain patterns of unequal access. As a female FGD participant explained:

"...Generally, the procedure for acquiring land by men and women is the same except for the fact that in the case of women, her husband or a male relative is required to lead the way. This consideration is necessary to give the landowner the assurance that the prospective land user (in this case a woman) is capable of maintaining the land..." (Interview 5, Women-only FGD, Kakum).

\footnotetext{
12 The Ankasa data show that majority of female-managed landholdings (57\%) as opposed to male-managed ones (27\%) were acquired via inheritance which is not very surprising to the extent that access to land through the inheritance mode remains the primary access route in the studied communities especially amongst natives of the landholding families. This may also reflect the challenges women face in acquiring land through market channels (discussed in body of paper)
} 


\section{Land Use Policy}

Furthermore, unilaterally negotiating land access without the husband risks being misconstrued as having an illicit affair with the landowner as a female FGD participant clearly explains another rationale behind such arrangement:

"...Aside from the fact that intermediaries serve as witnesses to the transaction, we married women ought to get our spouse or male relatives involved in negotiating for land to avoid any backlash of engaging in extra-marital affairs in the case of male landowner..." (Interview 7, Women-only FGD, Kakum).

Nuancing the narrative that women are passive by-standers in land acquisition arrangements, women discussants in FGDs also highlighted the security benefits associated with having male intermediaries, most importantly to avoid being cheated by landowners. They argued that in the event of any dispute the men could more ably act and defend their (women) land rights.

Traditional gender patterns in terms of division of labour also tend to give men the relative advantage in gaining access to more secure land (rights) as compared to women. For instance, the clearing of virgin forest patch by either a man or woman confers usufructuary rights in a communal land but owing to gender division of labour and social norms women are often precluded. This is because of the stereotypical view that women are "naturally weak" to undertake certain farming activities considered as the preserve of men (cf. Duncan and Brants, 2004; Duncan, 2010). During the women only FGDs, women also recounted that they were customarily required to assist their husbands on their farms as part of their marital obligations leaving them with limited time to develop their own farms. Although it has been observed that it was common for women to gain access to land (rights) through inter-vivos gifts as rewards for their labour contribution in establishing cocoa farms in southwestern Ghana (Quisumbing et al. 2001; Duncan, 2010), it worth underscoring that in contemporary times gifts are seldom a viable means of accessing land considering the current tenurial transformations that favour of market channels of access. This observation is supported by the fact that $59 \%$ and $41 \%$ of women in Kakum and Ankasa respectively accessed their landholdings through market channels (see Table 6).

Aside from the socio-cultural norms that inhibit women accessing land, the lack of requisite financial resources also operated to constrain women's access to land. A typical view is that:

"...As a woman, I can access land for whatever purpose provided I have the money to pay for it. The men can sometimes be selfish and would not consider paying for the land on behalf of their spouses. As such, you the woman can unilaterally proceed to acquire it for yourself and children once you have the means [albeit with a male intermediary] which is not easy at all..." (FGD 2, Ghana-Nungua-FGD, Ankasa).

With the increasing monetisation of the land acquisition process in the study regions, increasingly financial constraint is, in combination with socio-cultural norms, the most significant impediment to women's land access. Most of the women in the studied communities were relatively poor and therefore dependent on men. Building on the findings of Kasanga et al. (1996) and Kasanga and Kotey (2001) it can be concluded that tenurial factors per se cannot be blamed for the problems of inequities in land access; but rather, non-tenurial factors are critical. This highlights in the necessity of multi-faceted and interconnected efforts to address gender inequalities in accessing land. 


\section{Land Use Policy}

\subsection{Complexities in Land Access and the Youth: Assessing the Intergenerational Equity Problem?}

In almost all the studied communities (and particularly in Kakum), respondents stressed that growing land scarcity and the commodification of land is making it increasingly difficult for young people to obtain land for farming due to the growing land scarcity and marketization of land. Most young people, who do not have adequate financial resources to purchase or rent land have to settle for customary licenses and/ or caretaker arrangements (see table 1). Native youths in particular are finding it difficult to access land. As disclosed by one key informant in Kakum, most land-rich natives now prefer to grant out their lands to migrants (instead of fellow natives) who were prepared to pay higher sums as drink money. He further asserted that the difficulty in obtaining access to farmland in the studied communities has contributed to the general disillusionment of the youth in farming altogether.

The on-going tenurial transformations have evidently shifted patterns of social exclusion and economic insecurity with young people being among those finding it increasingly difficult to access commodified and marketized land. In response, customary tenure institutions are adapting, ostensibly to safeguard the right of future generations to land in the studied communities. Most notably, customary freehold grants are being transitioned to agricultural leases (of limited duration) particularly to new settler farmers in the studied communities (see table 1). In Ankasa, some traditional authorities were at an advanced stage of introducing 10-year agricultural leases (subject to renewal) as replacement for all customary freeholds currently enjoyed by non-native farmers as a way of ensuring that the interest of the indigenous members of future generations is not compromised. Explaining the rationale for the somewhat 'radical approach', an educated community elder at one village in Ankasa had this to say:

".... even the laws of the land [i.e. the 1992 Constitution of Ghana] forbids the grant of freehold interest in any stool/ skin land. Therefore, our intention to replace customary freeholds enjoyed by the non-native farmers [including new settlers] from other parts of Ghana with 10-year renewal leases is in accordance with the law. It's simply meant to safeguard our interest and that of our future generations yet unborn..." (Interview 6, Ankasa).

The above observation exemplifies an instance where customary authorities are drawing on statutory legislation in redefining local rules and norms on land access with the underlying logic of safeguarding intergeneration equity. For instance, Article 267 (5) of the 1992 Constitution stipulates that "subject to the provisions of this Constitution, no interest in, or right over, any stool land in Ghana shall be created which vests in any person or body of persons a freehold interest howsoever described". Arko-Adjei's (2011) study of three peri-urban locations in Ghana found similar evidence where leaseholds have been adopted based on social security considerations. Thus, the foregoing supports the view that customary tenure institutions can evolve and adapt amid on-going transformations to meet the needs of community members without direct state intervention. However, the extent to which the conversion of customary freeholds to agricultural leases will be utilized to address concerns about intergenerational equity relative to simply entrenching the power of the chiefs remains to be seen.

\subsection{Community membership and access to land}




\section{Land Use Policy}

Whereas familial connections and community membership (i.e. nativity) still remain important avenues to accessing land in the study areas (see table 4), the increasing monetisation of access arrangements raises some questions as to the extent of their applicability in land access considerations in the long-term. Table 7 shows areas of landholding disaggregated by ethnicity and table 8 show results on the main modes of respondents' access to their landholding by ethnicity.

Table 7: Landholding Area by Ethnicity

\begin{tabular}{|c|c|c|c|c|}
\hline \multirow{2}{*}{$\begin{array}{c}\text { Size of Farm } \\
\text { (Acreage) }\end{array}$} & \multicolumn{2}{|c|}{ Kakum Region } & \multicolumn{2}{c|}{ Ankasa Region } \\
\cline { 2 - 5 } & $\begin{array}{c}\text { Indigene } \\
(\mathrm{n}=17)\end{array}$ & $\begin{array}{c}\text { Migrant } \\
(\mathrm{n}=215)\end{array}$ & $\begin{array}{c}\text { Indigene } \\
(\mathrm{n}=40)\end{array}$ & $\begin{array}{c}\text { Migrant } \\
(\mathrm{n}=108)\end{array}$ \\
\hline$\leq 3$ & $23 \%$ & $24 \%$ & $33 \%$ & $14 \%$ \\
\hline $4-6$ & $29 \%$ & $33 \%$ & $33 \%$ & $29 \%$ \\
\hline $7-9$ & $12 \%$ & $15 \%$ & $5 \%$ & $18 \%$ \\
\hline $10-12$ & $12 \%$ & $10 \%$ & $5 \%$ & $9 \%$ \\
\hline $13-15$ & $18 \%$ & $5 \%$ & $2 \%$ & $5 \%$ \\
\hline $16+$ & $6 \%$ & $13 \%$ & $22 \%$ & $26 \%$ \\
\hline
\end{tabular}

Table 8: Common Access Routes to Landholdings by Ethnicity

\begin{tabular}{|l|c|c|c|c|}
\hline \multirow{2}{*}{ Mode of Acquisition } & \multicolumn{2}{|c|}{ Kakum } & \multicolumn{2}{c|}{ Ankasa } \\
\cline { 2 - 5 } & \multicolumn{2}{|c|}{ Household Plots } & \multicolumn{2}{c|}{ Household Plots } \\
\cline { 2 - 5 } & $\begin{array}{c}\text { Indigene } \\
(\mathrm{n}=29)\end{array}$ & $\begin{array}{c}\text { Migrant } \\
(\mathrm{n}=491)\end{array}$ & $\begin{array}{c}\text { Indigene } \\
(\mathrm{n}=73)\end{array}$ & $\begin{array}{c}\text { Migrant } \\
(\mathrm{n}=170)\end{array}$ \\
\hline Gift & $7 \%$ & $1 \%$ & $9 \%$ & $7 \%$ \\
\hline Inheritance & $38 \%$ & $35 \%$ & $69 \% * * *$ & $15 \% * * *$ \\
\hline Purchase & $3 \%$ & $1 \%$ & $7 \%$ & $5 \%$ \\
\hline Sharecropping & $52 \%$ & $62 \%$ & $15 \% * * *$ & $71 \% * * *$ \\
\hline Rental & 0 & $1 \%$ & 0 & $2 \%$ \\
\hline
\end{tabular}

Inferring from tables 7 and 8, there are no significant differences in the areas of landholding and means of acquiring land between natives and migrant groups particularly in Kakum. This seem to suggest that native groups did not enjoy any preferential access as they are somewhat restricted to acquiring land through market channels (mostly sharecropping), just like their migrant counterparts. In Ankasa, however, native groups still had better opportunities to acquire relatively more secure land (through inheritance - non-market pathway) but not larger plots per se amid ongoing tenurial transformation (Tables 7 and 8). From a native perspective, the shifting of access patterns towards market-oriented pathways (occasioned by the growing land demand) seem to give an indication of the rapid erosion of the inherent 'social right' to land enjoyed by native groups under customary land tenure system, particularly in Kakum. A typical view of an indigenous farmer in Kakum is illustrative:

"...Accessing land is now money matters. It does not follow whether you are from here [native] or not. A migrant who has the purchasing power can acquire land at the expense of you the native..." (FGD 1, Nkwantannan-FGD, Kakum).

This puts to question Aryeetey et al.'s (2007) claim that ethnicity fosters a sense of bonding ensuring that indigenous people are able to reject the right of migrants to land even when migrants are fellow citizens. It therefore does appear that in the spate of current transformations, one's economic status 


\section{Land Use Policy}

other than nativity is perhaps the overriding factor in gaining access to land. It was gathered from the qualitative interviews that on average, it cost natives between 100-350 Ghana cedis to acquire an acre of farmland whilst migrants could pay up to the tune of 500 Ghana cedis to acquire the same size of farmland in Kakum. Clearly, access conditions have changed from the mere presentation of customary drinks (aseda) to the landowner to include cash payments, even in the case of natives.

In this light, whereas the marketization process seems to create opportunities for certain people who hitherto could not gain access to land to do so (Yaro, 2010; Quisumbing et al. 2001), it also could potentially contribute to both inequities in land access from the perspective of native groups, particularly the poorer and less powerful natives. This is particularly pronounced in the case of local women and the youth who appear to bear the brunt of the increasingly monetised access arrangements.

A further source of strain with respect to community membership and land access concerns changes with respect to sharecropping arrangements. Two key issues were consistently raised: (1) payment of huge consideration as 'nsa sika' (drink money) to traditional authorities and/ or landowners as a precondition for gaining access to land, and (2) variations of the initial terms and conditions of grant at will by landowners occasioned by the seemingly ambiguous emergent rules and conditions governing land access arrangements.

From the qualitative interviews, whereas traditional authorities in Kakum and Ankasa insisted that land is customarily not for sale, most migrant farmers held a contrary view alluding to the colossal considerations payable for accessing land as tantamount to outright alienation. Extracts from two interviews with an elder of the Stool A and representatives of the migrant farmers in Ankasa sums up the contrasting positions above:

"...The lands are not sold to anybody but granted out to prospective users usually on sharecrop (i.e. Abunu or Abusa) or land rental basis. They make small payment in the form of drink money to the chief and the terms and conditions of use are spelt out before cultivation of the land..." (Elder of Stool A-Ankasa).

"...We paid gargantuan amounts to the customary authorities prior to acquiring our sharecropped lands. We currently pay GHS 250.00 per acre annually to the chiefs on top of additional payments (disguised as developmental levies) to ensure continual use of the land..." (Ohiamadwen-Fiasoro Rep. 1, Ankasa).

The above statements highlight the tensions between traditional authorities and migrant farmers regarding the conditions of access to land especially in the Ankasa area. Kasanga and Kotey (2001) assert that the drink money payable to landowners is often equivalent to the market value of the land which makes it difficult to distinguish between outright sale and other forms of land transactions. Elsewhere in southwestern Ghana, similar accounts on landlord-tenant relations have been reported by Boone and Duku (2012), Boni (2005) and Alhassan and Manuh (2005). Moreover, the foregoing developments have also created 'spaces' or opportunities for other actors apart from traditional authorities (i.e. chiefs and Abusuapanyins) to participate in customary land allocation in view of the prospects of profiting from the upsurge in land values compounded by the growing land scarcity and ambiguity of emergent rules and conditions of land access in the study areas. It was gathered from the qualitative interviews and observations that unilateral alienation of land (notably 


\section{Land Use Policy}

migrant to migrant transfers) was common in both study areas even though the traditional authorities frowned upon such arrangements as tantamount to adverse claims to their title in land. Almost all discussants who participated in the FGDs alluded to the practice of land-rich customary usufructs (mostly early arrivals) accustomed to granting out portions of their land to third parties - especially new arrivals and other landless households - usually on sharecropping or rental basis in their respective communities. It is noteworthy, however, that such farmer-to-farmer alienation without the appropriate legitimation by the original landowners (i.e. traditional authorities) are potential conflict traps and sources of insecurity as an elder of Stool X in Kakum demonstrated:

"...Although it is customarily illegal especially for users of stool lands to alienate such lands to third parties without recourse to the traditional authorities, we are very much aware it is happening. Such transfers however are not legitimate and for that matter the supposed beneficiaries risk losing devolved land rights as we [customary authorities] do not know them..." (Interview 4, Kakum).

The foregoing statement highlights the contrasting position of traditional authorities on third-party alienation of acquired land rights with far-reaching implications for security of tenure from tenant farmers point of view as afore-mentioned.

\section{Discussion - the Implications of Changing Land Tenure for Equitable Land Access}

While customary land tenure is evolving towards individualisation based on commodification and marketisation in the study areas, the emergent changes in tenurial dynamics are far more complex than the often-assumed linear conceptualisation by the evolutionary theory of land rights (Platteau, 1996; 2000). Understanding the socio-cultural embeddedness of tenurial transformations is critical to the design and implementation of appropriate and effective land policy interventions aimed toward inclusive and equitable outcomes at the local level.

The increasingly monetised access arrangements (in the wake of ongoing transformation in the local tenurial regimes) have far-reaching negative implications for the poor and vulnerable social groups. Whereas the current marketisation process may create new opportunities for the hitherto socially disadvantaged to easily acquire or own land (Yaro, 2010; Chimhowu and Woodhouse, 2006; Aryeetey et al. 2007), issues of economic insecurity often precludes them from effectively doing so in practice (Sections 4.2 and 4.3). Taking the case of most rural women and the youth, for instance, their inability or limited capacity to mobilize the requisite financial resources would almost invariably imply that they are constrained from effectively participating in the emerging local land markets. Even so, those who successfully acquire land could potentially loose it in the event of counter claims to ownership (rooted in differing perspectives of ownership, influence and authority) to the extent that they are poor and therefore unable to afford justice within the formal court system (cf. Kuusaana et al. 2013).

Economic transformations concerning land have not been mirrored in social or cultural realms. The dominance of men in the customary land delivery process is a manifestation of deep-seated sociocultural norms and perceptions that significantly influence secure access to and control of land, especially undermining access to land for migrant women. These norms explain why, despite current statutory laws providing for equal rights in land by men and women, gender-based inequality 


\section{Land Use Policy}

is still pervasive in most parts of Ghana (see Sewornu, 2010; Dery, 2015; Lambrecht, 2016) and elsewhere in SSA (see Daley and Englert, 2010; Garber, 2012).

The prevailing situation of most women, and youth, is further exacerbated by the limited availability of off-farm economic opportunities in the rural areas. Consequently, the rich and powerful local elites are better positioned to benefit disproportionately from the emergence of market-based access mechanisms thereby relegating the poor and vulnerable social groups into a state of landlessness or near-landlessness. It therefore follows that a balance between market efficiency and social equity considerations remains crucial towards ameliorating the prevailing tenurial situation and achieving pro-poor outcomes (Ninsin, 2015; Broegaard, 2013).

Against this background, the current focus of Ghana's ongoing land reform (i.e. G-LAP) on prioritizing market efficiency arguments over social equity considerations risks further entrenching and exacerbating existing inequalities, social exclusion and tenure insecurity amongst the poor and vulnerable social groups, especially in rural areas like the study areas. One way forward in addressing these social equity concerns is the institution of social safeguards as part of the broader implementation guidelines of government land policies to better protect the land rights of poor and vulnerable social groups. To these ends, the creation of legal aid and social service support centres in addition to special loan schemes under the LEAP ${ }^{13}$ and Planting for food programmes could afford women and the youth the opportunity to effectively participate in emerging monetised rural land markets. It is noteworthy, however, that the normative question regarding access to land being shaped by ethnicity or wealth should be a major point of political deliberation.

\section{Conclusion}

The paper has underlined how on-going transformation in the tenurial dynamics in the study areas following growing land scarcity and commodification has resulted in the redefinition of local norms and rules of land access and ownership. It has responded to some of the recent calls by scholars like Cao (2012), Lawry et al. (2017) and Robinson et al. (2014) on the need for systematic examination of the nature of existing customary tenure institutions and arrangements within their wider sociocultural and political contexts to afford sufficient understanding of how they shape or impact tenurial dynamics at the local level.

Ultimately, it is evident from the foregoing analysis that the 'self-transformation' or dynamism of the customary land tenure system is inadequate in addressing the issues of inequalities and difficulty in access to and control of land particularly by the vulnerable social groups (i.e. the local youth, women and the poor) in the study areas. The current tenurial dynamics, which are increasingly characterised by individualisation and monetisation, generate socially differentiated impacts with respect to considerations of equity. Generally, they have favoured wealthier individuals and households regardless of ethnicity or migratory status and have undermined the security of natives/ autochthonous and poorer households. This is evidenced by the seeming spaces or opportunities created in the emergent tenurial relations for powerful actors to advance their individual interests at the expense of the vulnerable groups thereby resulting in a situation of winners and losers. It can

\footnotetext{
13 The Livelihood Empowerment Against Poverty (LEAP) and Planting for Food are government-led social initiatives geared towards poverty alleviation (through strategic cash transfers) and reviving Ghana's agricultural sector.
} 


\section{Land Use Policy}

therefore be concluded that the emergent changes in conditions of access and control of land by the different social groups is not intrinsic in the customary tenure system per se but largely products of manipulations by interested parties (mostly chiefs and local elites) who exploit these seeming opportunities created for their own pecuniary benefit as opposed to the collective interest of the landholding community (Yaro and Zackaria, 2008).

Whilst recognising the limitation of two case studies in generalising for the whole of Ghana and by extension SSA, the paper underscores the need for a theoretical shift of the focus of land tenure reforms away from approaches geared towards promoting efficiency or merely lauding customary tenure arrangements in favour of more flexible approaches that accommodate the complexity of change and its social embeddedness across contexts in order to effectively mitigate the social inequities rooted in access to land. Efforts to address these concerns in policy must not only recognize how non-tenurial factors influence the operation of tenurial rules but should also be explicit about the political and ethical trade-offs involved in land reform which inevitably lead to opening windows of opportunities for some individuals and groups, while closing them for others.

\section{ACKNOWLEDGEMENTS}

We would like to thank Gideon Tuffour and Godfred Bempah for research assistance. We are grateful to the traditional leaders and community members of the Kakum and Ankasa regions and other research participants for their contributions to the research process.

\section{References}

Abdulai, R. T., \& Ndekugri, I. E. (2007). Customary landholding institutions and housing development in urban centres of Ghana: case studies of Kumasi and Wa. Habitat International, 31(2), 257-267.

Agbosu, L., Awumbilla, M., Dowuona-Hammond, C. \&Tsikata, D. (2007). Customary and statutory land tenure and land policy in Ghana. ISSER Technical Publication No. 70

Alhassan, O. \& Manuh, T. (2005). Land registration in Eastern and Western Regions, Ghana. IIED, UK.

Amanor, K.S. (2006). Rural youth and the right to a livelihood in Ghana. Paper for Conference on youth and the global south: religion, politics and the making of youth in Africa, Asia and the Middle East'. Dakar, Senegal, CODESRIA.

Amanor, K.S. (2010). Family values, land sales and agricultural commodification in south-eastern Ghana. Africa, 80, pp. 104-125.

Amanor, K.S. (2012). Land Governance in Africa: How Historical Context Has Shaped Key Contemporary Issues Relating to Policy on Land. Framing the Debate Series 1. International Land Coalition, Rome, Italy.

Anaafo, D. (2015). Land reforms and land rights change: A case study of land stressed groups in the Nkoranza South Municipality, Ghana. Land Use Policy, 42, 538-546.

Antwi, Y.A. (2006). Strengthening customary land administration: A DFID/World Bank sponsored project in Ghana. In 5th FIG regional conference on 'Promoting land administration and good governance', March (pp. 8-11).

Appiah, D. (2012). The politics of traditional-federal state formation and land administration reform in Ghana: 1821-2010. Unpublished PhD submitted to the University of York, UK. 


\section{Land Use Policy}

Arko-Adjei, A. (2011). Adapting land administration to the institutional framework of customary tenure: the case of peri-urban Ghana. IOS Press.

Aryeetey, E., J.R.A. Aryee, K.A. Ninsin \& D. Tsikata (2007). The politics of land tenure reform in Ghana: From the Crown Lands Bills to the Land Administration Project. Institute of Statistical, Social \& Economic Research (ISSER), Legon, University of Ghana.

Barry, M. \& Danso, E.K. (2014). Tenure security, land registration and customary tenure in a periurban Accra community. Land use policy, 39, pp.358-365.

Benneh, G., Kasanga, R.K. \& Amoyaw, D. (1996). Land tenure and women's access to agricultural land in the household: A case study of three selected districts in Ghana. The Changing Family in Ghana, p.169.

Bentsi-Enchill, K. (1964). Ghana land law, an exposition, analysis and critique. London: Sweet \& Maxwell; Lagos: African Univ. Press 1964.

Berry, S. (1993). No condition is permanent: The social dynamics of agrarian change in sub-Saharan Africa. Madison, WI: University of Wisconsin Press.

Berry, S. (2002). 'Debating the land question in Africa'. Comparative Studies in Society and History 44 (4): 638-668.

Berry, S. (2009). Property, authority and citizenship: land claims, politics and the dynamics of social division in West Africa. Development and Change, 40(1), 23-45.

Biitir, S.B. \& Nara, B.B. (2016). The role of Customary Land Secretariats in promoting good local land governance in Ghana. Land Use Policy, 50, pp.528-536.

Blocher, J. (2006). Building on custom: land tenure policy and economic development in Ghana. Yale Human Rights and Development Law Journal, 9, p.177.

Boni, S. (2005). Clearing the Ghanaian forest: Theories and practices of acquisition, transfer and utilisation of farming titles in the Sefwi-Akan area. Institute of African Studies.

Boone, C., \& Duku, D. K. (2012). Ethnic land rights in western Ghana: landlord-stranger relations in the democratic era. Development and Change, 43(3), 671-693.

Braimah, I., Tudzi, E. P. \& Baah-Ennumh, T. Y. (2009). Land tenure as a challenge to the sustainability of the Amokwao Community Resource Management Area in Ghana. Journal of Sustainable Development in Africa, 11(1), 128-148.

Broegaard, R.B. (2013). Biting the barefoot: Land titles and tenure security in the context of inequality. DIIS, Danish Institute for International Studies.

Bromley, D.W. (2009). Formalising property relations in the developing world: The wrong prescription for the wrong malady. Land Use Policy, 26(1), pp.20-27.

Bugri, J.T. (2008). The dynamics of tenure security, agricultural production and environmental degradation in Africa: Evidence from stakeholders in northeast Ghana. Land Use Policy, 25, 271 285.

Bugri, J.T. (2012). Sustaining customary land secretariats for improved interactive land governance in Ghana. In Annual World Bank Conference on Land and Poverty, Washington, DC, April 23-26. Byamugisha, F. (2013). Securing Africa's land for shared prosperity: a program to scale-up reforms and investments. Africa development forum series. World Bank. Available online at (https://openknowledge.worldbank.org/handle/10986/2150).

Bugri, J.T. and Yeboah, E. (2017). Understanding changing land access and use by the rural poor in Ghana. IIED, London. Available online at http://pubs.iied.org/pdfs/17595IIED.pdf (Accessed on 26/01/2019). 


\section{Land Use Policy}

Cao, L. (2012). Informal institutions and property rights. In Brigham-Kanner Prop. Rts. Conf. J. (Vol. 1, p. 263).

Chimhowu, A. \& Woodhouse, P. (2006). Customary vs private property rights? Dynamics and trajectories of vernacular land markets in Sub-Saharan Africa. Journal of Agrarian Change, 6(3), 346-371.

Clarke, R.A. (2009). Securing Communal Land Rights to Achieve Sustainable Development in SubSaharan Africa: Critical Analysis and Policy Implications. Law Env't \& Dev. J., 5, p.130.

Cotula, L. (ed) (2007). Changes in “customary” land tenure systems in Africa. IIED, London.

Creswell, J. W. \& Clark, V. L. P. (2011). Designing and conducting mixed methods research. SAGE Publications, $2^{\text {nd }}$ Edition.

Creswell, J. W. (2013). Research design: Qualitative, quantitative, and mixed methods approaches. Sage publications.

Daley, E. \& Englert, B. (2010). Securing land rights for women. Journal of Eastern African Studies, 4(1), 91-113.

Deininger, K. (2003). Land policies for growth and poverty reduction. Word Bank and Oxford University Press.

De Soto, H. (2000). The mystery of capital: Why capitalism triumphs in the West and fails everywhere else. Basic Books, New York.

Djokoto, G. \& Opoku, K. (2010), Land tenure in Ghana: Making a case for the incorporation of customary law in land administration and areas for intervention by the Growing Forest Partnership. Doss, C., Kovarik, C., Peterman, A., Quisumbing, A. and Bold, M. (2015). Gender inequalities in ownership and control of land in Africa: myth and reality. Agricultural Economics, 46(3), pp.403434.

Dowuona-Hammond, C. (2003). Report on State Land Management and Its Impact on Women and the Poor in Ghana. GTZ Legal Pluralism and Gender Project (Land Law Focal Area), Accra, Ghana Duncan, B. A. (2010). Cocoa, marriage, labour and land in Ghana: Some matrilineal and patrilineal perspectives. Africa, 80(02), 301-321.

Duncan, B.A. \& Brants, C. (2004). Access to and control over land from a gender perspective: A study conducted in the Volta Region. Commissioned by the SNV Netherlands Development Organisation - Ghana Office and the Gender and Development Unit of the Food and Agriculture Organisation of the UN Regional Office for Africa (FAORAF). Accra, Ghana: SNV/FAO.

Falk, A.R. (2016). Ahead of the curve: promoting land tenure security in sub-Saharan Africa to protect the environment. Seattle J. Soc. Just., 15, p.1.

FAO (2002). Land tenure and rural development, land tenure studies, FAO, Rome.

Firmin-Sellers, K. (1995). The politics of property rights. American Political Science Review, 89(04), pp.867-881.

Garber, B. (2012). Caught between customary and state law: women's land rights in Uganda in the context of increasing privatization of land tenure systems. (Available online at http://mokoro.co.uk/wp-content/uploads/Diplomarbeit_BarbaraGarber_01.pdf ).

GNA (Ghana News Agency) (2018). Women contribute 60\% to agriculture development in Ghana. Available online at https://www.ghanabusinessnews.com/2018/11/23/women-contribute-60-toagriculture-development-in-ghana/ (Accessed on 26/01/2019).

Goldstein, M. \& Udry, C. (2008). The profits of power: land rights and agricultural investments in Ghana. Journal of Political Economy, Vol. 116, No.16, pp. 9 


\section{Land Use Policy}

Government of Ghana (1999). National Land Policy. Accra, Ghana.

Hammersley, M. \& Atkinson, P. (2007). Ethnography: Principles in practice. Routledge.

Joireman, S.F. (2006). Applying property rights theory to Africa: the consequences of formalizing informal land rights. In meeting of the International Society for New Institutional Economics, Boulder.

Joireman, S.F. (2008). The mystery of capital formation in Sub-Saharan Africa: women, property rights and customary law. World Development, 36(7), pp.1233-1246.

Kalabamu, F.T. (2014). Divergent paths: Customary land tenure changes in Greater Gaborone, Botswana. Habitat International, 44, pp.474-481.

Kasanga, R. K., Cochrane, J., King, R., \& Roth, M. (1996). Land markets and legal contradictions in the peri-urban area of Accra Ghana: informant interviews and secondary data investigations. Land Tenure Centre.

Kasanga, K. \& Kotey, N. A. (2001). Land management in Ghana: building on tradition and Modernity. IIED, London.

Kasanga, K. (2001). Land resource management for agricultural development in Ghana. RICS Research Foundation.

Kasanga, K. (2002). World Bank land policy for pro-poor development policy research report: a review. Accra, Ghana.

Kidido, J.K., Bugri, J.T. \& Kasanga, R.K. (2017). Dynamics of youth access to agricultural land under the customary tenure regime in the Techiman traditional area of Ghana. Land Use Policy, 60, pp.254-266.

Knight, R. S. (2010). Statutory recognition of customary land rights in Africa: an investigation into best practices for law-making and implementation. FAO Legislative Study, (105).

Krantz, L. (2015). Securing Customary Land Rights in Sub-Saharan Africa. Available online at https://gupea.ub.gu.se/bitstream/2077/38215/1/gupea_2077_38215_1.pdf

Kuusaana, E.D., Kidido, J.K., Appiah, M.N. \& Mireku, K.O. (2013). Alternative dispute resolution by Chiefs and Tendamba: a case study of Kumasi and Was Traditional Areas.

Kuusaana, E.D. \& Gerber, N. (2015). Institutional synergies in customary land markets - selected case studies of large-scale land acquisitions (LSLAs) in Ghana. Land, 4(3), pp.842-868.

La Anyane, S. (1962). Agriculture in the general economy: Factors affecting agricultural production, in Wills, J. (ed.), Agriculture and Land Use in Ghana. Oxford University Press.

Lambrecht, I. (2016). "As a husband I will Love, Lead, and Provide". Gendered Access to Land in Ghana. World Development, Vol. 88,188-200.

Lambrecht, I. \& Asare, S. (2016). The complexity of local tenure systems: A smallholders' perspective on tenure in Ghana. Land Use Policy, 58, pp.251-263.

Lawry, S., Samii, C., Hall, R., Leopold, A., Hornby, D. \& Mtero, F. (2017). The impact of land property rights interventions on investment and agricultural productivity in developing countries: a systematic review. Journal of Development Effectiveness, 9(1), pp.61-81.

Lund, C. (2011). Property and citizenship: conceptually connecting land rights and belonging in Africa. Africa Spectrum, 46(3), pp.71-75.

Mamdani, M. (1999). Historicizing power and responses to power: indirect rule and its reform. Social Research, pp.859-886.

Meinzen-Dick, R. and Mwangi, E. (2009). Cutting the web of interests: Pitfalls of formalizing property rights. Land Use Policy, 26(1), pp.36-43. 


\section{Land Use Policy}

Miles, M. B. \& Huberman, A. M. (1994). Qualitative Data Analysis, $2^{\text {nd }}$ edition, Sage, Thousand Oaks, CA.

Mwesigye, F., Matsumoto, T. \& Otsuka, K. (2017). Population pressure, rural-to-rural migration and evolution of land tenure institutions: The case of Uganda. Land Use Policy, 65, pp.1-14.

Ninsin, K. A. (2015). Land reforms in Ghana. Land reforms and natural resource conflicts in Africa: New Development Paradigms in the Era of Global Liberalization, 135.

Nkonya, E., Johnson, T., Kwon, H. Y. and Kato, E. (2016). Economics of Land Degradation in SubSaharan Africa. In Economics of Land Degradation and Improvement-A Global Assessment for Sustainable Development (pp. 215-259). Springer International Publishing.

Nkwae, B. (2006). Conceptual framework for modelling and analysing peri-urban land problems in Southern Africa (Vol. 69, No. 07).

Okoth-Ogendo, H.W.O. (2000). Legislative approaches to customary tenure and tenure reform in East Africa. Evolving land rights, policy and tenure in Africa., pp.123-134.

Okoth-Ogendo, H.W.O. (2002). The tragic African commons: A century of expropriation, suppression and subversion. Available online at https://www.africaportal.org/documents/9050/OP_24.pdf (Accessed on 23/07/2018).

Ollenu, N.A. (1962). Principles of customary land law in Ghana. Sweet and Maxwell, London.

Otsuka, K., Quisumbing, A.R., Payongayong, E. \& Aidoo, J.B. (2003). Land Tenure and the management of land and trees: the case of customary land tenure areas of Ghana. Environment and Development Economics, 8, 77-104.

Otsuka, K. \& Place, F. (2014). Changes in land tenure and agricultural intensification in subSaharan Africa. World Institute for Development Economics Research (WIDER) Working Paper, 51 .

Peters, P.E. (2009). Challenges in land tenure and land reform in Africa: Anthropological contributions. World Development, 37(8), pp.1317-1325.

Peters, P. E. (2013). Conflicts over land and threats to customary tenure in Africa. African Affairs, 112(449), 543-562.

Platteau, J. P. (1996). The Evolutionary Theory of Land Rights as Applied to sub-Saharan Africa: A Critical Assessment. Development and Change, 27(1), 29-86.

Platteau, J.P. (2000). Institutions, social norms, and economic development (Vol. 1). Psychology Press.

Pottier, J. (2005). Customary Land Tenure in Sub-Saharan Africa Today: Meanings and contexts. From the Ground Up: Land Rights, Conflict and Peace in Sub-Saharan Africa, pp.55-75.

Quan, J., Ubink, J. \& Antwi, A. (2008). Risks and opportunities of state intervention in customary land management: emergent findings from the land administration project Ghana. Contesting Land and Custom in Ghana. State, Chief and the Citizen, 183-208.

Quisumbing, A. R., Payongayong, E., Aidoo, J. B., \& Otsuka, K. (2001). Women's land rights in the transition to individualized ownership: Implications for tree-resource management in western Ghana. Economic Development and Cultural Change, 50(1), 157-182.

Ribot, J. C., \& Peluso, N. L. (2003). A theory of access. Rural sociology, 68(2), 153-181.

Robinson, B.E., Holland, M.B. \& Naughton-Treves, L. (2014). Does secure land tenure save forests? A meta-analysis of the relationship between land tenure and tropical deforestation. Global Environmental Change, 29, pp.281-293. 


\section{Land Use Policy}

Rudel, T.K. \& Hernandez, M. (2017). Land Tenure Transitions in the Global South: Trends, Drivers, and Policy Implications. Annual Review of Environment and Resources, 42, pp.489-507. Schoneveld, G.C. \& German, L. (2014). Translating legal rights into tenure security: lessons from the new commercial pressures on land in Ghana. Journal of Development Studies, 50(2), pp.187203.

Sewornu, R. E. (2010). The role of good governance in improving women's access right to land. OIDA International Journal of Sustainable Development, 1(5), 37-53.

The 1992 Constitution of the Republic of Ghana.

Ubink, J. (2008). Struggles for land in peri-urban Kumasi and their effect on popular perceptions of chiefs and chieftaincy. Contesting land and custom in Ghana: State, Chief and the Citizen, 155-182. Verma, R. (2014). Land grabs, power, and gender in East and Southern Africa: So, what's new?. Feminist Economics, 20(1), pp.52-75.

Whitehead, A. \& Tsikata, D. (2003), Policy Discourses on Women's Land Rights in sub-Saharan Africa: The Implications of the re-turn to the Customary. Journal of Agrarian Change 3 (1 and 2): pp. 67-112.

Woodman, G. (2011). A survey of customary laws in Africa in search of lessons for the future, pp.930. In Fenrich, J., Galizzi, P. and Higgins, T.E. (Eds.) (2011). The future of African customary law. Cambridge University Press.

World Bank (2006). Equity and development. Washington: World Bank.

Yaro, J.A. \& Zackaria, A.I. (2008). Evolution of customary land tenure systems and sustainable livelihoods in northern Ghana. ISSER, University of Ghana.

Yaro, J. A. (2010). Customary tenure systems under siege: contemporary access to land in Northern Ghana. GeoJournal, 75(2), 199-214.

Yankson, P., Asiedu, A. \& Yaro, J. (2009). Land rights and vulnerabilities in the Kete Krachi pilot customary land secretariat area. Unpublished paper from Department of Geography and Resource Development, University of Ghana, Accra.

Yin, R. (2003). Case study research - design and methods, third edition. Applied Social Research Methods Series, Vol. 5, Sage Publications, London. 